(C) 2020, The Authors. Published by FASS Inc. and Elsevier Inc. on behalf of the American Dairy Science Association ${ }^{\circledR}$. This is an open access article under the CC BY-NC-ND license (http://creativecommons.org/licenses/by-nc-nd/4.0/).

\title{
A segmentation of Swiss fluid milk consumers and suggestions for target product concepts
}

\author{
Mathilde Delley* (1) and Thomas A. Brunner ${ }^{\circ}$ \\ School of Agricultural, Forest and Food Sciences, Berne University of Applied Sciences, 3052 Zollikofen, Switzerland
}

\begin{abstract}
The objective of this study was to understand the priorities and motives of Swiss consumers when choosing and buying fluid milk and to provide evidencebased recommendations for the development of target product concepts and category adaptations. Data were collected through a postal survey sent to a randomly selected sample of German-speaking Swiss residents, yielding a final sample size of $n=712$ (39\% response rate). Hierarchical cluster analysis disclosed the presence of 3 distinct consumer segments: the uncompromising consumers (24\%), who have high and numerous expectations; the locavores $(56 \%)$, who ensure that they consume primarily milk of local origin; and the indifferent consumers (20\%), who have modest expectations, especially in taste, origin, and production conditions. The market review revealed that none of the 7 largest market players offered the right product mix to match the needs of its effective or targeted consumers. Overall, the current offer is too broad and untargeted. A large share of the offer lacks sufficient differentiation; furthermore, available added-value concepts often do not combine the right product attributes. Based on these results, 5 product concepts were elaborated. Two products were designed for the uncompromising consumers: a protein-enhanced, semi-skimmed (1.5\%) milk and a fair milk (fair price paid to the milk producers); a twin concept was designed for the locavores: a $100 \%$ local pasteurized milk available in both conventional and organic quality; and one product was designed for the indifferent consumers: an all-purpose, long-life, part-skimmed $(2.5 \%)$ milk. By including the product concepts dedicated to their targeted consumers' segments and downsizing their assortment depth, retailers could optimize their sales per square foot.
\end{abstract}

Key words: fluid milk, consumer behavior, cluster analysis, segmentation, target marketing

Received July 25, 2019.

Accepted December 18, 2019.

*Corresponding author: mathilde.delley@windowslive.com

\section{INTRODUCTION}

Fluid milk, also called drinking milk, is a staple food in many cultures and has been on retailers' shelves from the beginning of the dairy industry. However, this oncecentral component of the diet is losing importance, especially in the mature European and North American markets, to other more sophisticated dairy products, milk substitutes, or other food categories (Cessna and Law, 2017; Newton, 2017). The concerning evolution of the fluid milk market, which nevertheless accounted for $11 \%$ of raw milk processed in the European Union in 2017 (Eurostat, 2018), has received little attention from the scientific community. Most available studies focus on the influence of specific factors or are limited to analysis of the evolution of a particular type of fluid milk. However, to capture the appropriate levers to counter the negative evolution of the fluid milk market, it is necessary to study consumers' perceptions across the entire fluid milk category and include a wide range of potential factors in the analysis. Only by incorporating consumer perceptions in dairy foods can products be developed that are likely to be successful on the market (Esmerino et al., 2017; Pinto et al., 2018; Speight et al., 2019). By clustering consumers into various segments, it is possible to understand the problem more deeply, reacting to each segment's needs and developing products accordingly. This was our approach in the present study.

The characteristics considered by consumers when choosing and purchasing fluid milk can be classified in 2 main categories: intrinsic and extrinsic product attributes. Taste, heat and mechanical treatments, macro- and micronutrient content or supplementation, food safety, and shelf life are intrinsic attributes, whereas price, production method and place, manufacturer, brand, packaging size, and design are extrinsic attributes. At first sight, the hierarchy of attributes seems to vary across countries and regions. Nutritional composition an intrinsic attribute plays a more dominant role in the United States, where calories, fat, protein, lactose, minerals, and vitamins content are the key differentiating elements between different products 
(Lopez and Lopez, 2009; Davis et al., 2012; Gulseven and Wohlgenant, 2017; McCarthy et al., 2017). Flavor, packaging size, price (Lopez and Lopez, 2009; Maehle et al., 2015; McCarthy et al., 2017; Harwood and Drake, 2018), and organic label or local production are also considered by some US consumer segments (Wolf et al., 2011; Gulseven and Wohlgenant, 2017; McCarthy et al., 2017; Harwood and Drake, 2018). European consumers, for their part, do not seem to give equal priority and importance to different product attributes. Although the importance of brand polarizes German consumers (Schröck, 2012), they show more congruence regarding sensitivity to price and regional production, both of which are extrinsic attributes (Emberger-Klein et al., 2016). For Belgian consumers, freshness and food safety (both intrinsic) are the most important buying attributes (de Graaf et al., 2016), whereas Italians' priorities vary from one region to another: Sicilians assign the greatest importance to the intrinsic digestibility, nutritional properties, and the taste of milk (Lanfranchi et al., 2017), whereas Venetians' choice is based on extrinsic attributes such as milk's region of origin, its manufacturer or reseller, and its price (Tempesta and Vecchiato, 2013). Although these differences among countries and regions are interesting, it must be kept in mind that these studies also differ in the research design applied and attributes investigated, which hinders a direct comparison. Indeed, most studies are either limited to a small number of factors or focus on a single milk type. Furthermore, consumer samples often lack representativeness.

On average, European consumers drank 61 L of milk per capita in 2015 [International Dairy Federation (IDF) cited in Bosanac et al., 2017]. Irish, Finnish, Estonian, British, and Maltese consumers pull the average upward, with consumption exceeding $100 \mathrm{~L}$ per capita per year (Zarrouki, 2015; IDF cited in Bosanac et al., 2017). Nevertheless, the overall fluid milk market volume has steadily declined during the last 3 decades in all countries of Western Europe (Zarrouki, 2015; INLAC, 2016; FranceAgriMer, 2017; MIV, 2017; OMSCO, 2017); this evolution has been linked, in part, to the maturity of the market combined with an aging population with fewer children drinking a lot of milk and more older people drinking less (Zarrouki, 2015).

Despite the relatively small size of the dairy beverage category (liquid-milk-based flavored beverages that can be fermented), manufacturers tend to focus their innovation efforts on it rather than on fluid milk, without completely neglecting this latter product line. Low fat content, environmentally friendly packaging, and lack of allergens are the 3 dominant selling points of new fluid milk product concepts in Europe (Zarrouki,
2015). Retailers, for their part, have developed a 2-fold strategy of aggressive pricing on undifferentiated product lines combined with the launch of medium-priced local, organic, or fair milk lines (a concept inspired by the fair-trade label, in which milk producers receive a higher price so that they can make a decent living from milk production; Lehnert, 2010; Zarrouki, 2015; MIV, 2017).

Following the same underlying trend as that of neighboring countries, the Swiss fluid milk market volume dropped by almost $40 \%$ in $15 \mathrm{yr}$ to $53.3 \mathrm{~kg}$ per person in 2016 (Leuenberger, 2017; USP, 2017). This negative trend was slightly compensated by the growth of the dairy beverage market (which reached $9.6 \mathrm{~kg}$ per capita per year in 2016). Merging the product categories together, the volume decline was only $30 \%$. According to the national dietary survey from 2014-2015 (OSAV, 2017), Swiss adults drink, on average, $110 \mathrm{~mL}$ of fluid milk and dairy beverages per day, which corresponds to $40.15 \mathrm{~L} / \mathrm{yr}$. The difference between this figure and the abovementioned $53.3 \mathrm{~kg}$ (about $51.75 \mathrm{~L}$; Charrondiere et al., 2012) can probably be attributed to the wastage occurring at the consumer stage (Obrist and Erdin, 2014; Delley and Brunner, 2018) and to the higher per capita consumption by children, who were excluded from the national dietary survey. In 2016, Swiss consumers spent an average of CHF 1.50 (1 CHF $=$ US $\$ 1.01$ in July 2019; X-Rates, 2019) for $1 \mathrm{~L}$ of fluid milk (USP, 2017). Although this price has essentially not changed in $30 \mathrm{yr}$, the volume of consumption fell by more than half during the same period (SSB, 1986; USP, 2001), resulting in a massive and continuous market value shrinkage. Taking a closer look at consumer prices, it appears that $1 \mathrm{~L}$ of regular whole or part-skim milk costs around CHF 1.15 (Paus et al., 2016), which is much less than in 1985 or 2000 . To compensate for this loss, retailers have developed new milk types with added value. This is how organic, local, pasture-raised, fair, or mountain labels (Conseil Fédéral, 2017) but also fortified or content-modified milks (e.g., lactosefree, mineral- or vitamin-enhanced) have appeared on the shelves. The introduction of these products has not only helped to maintain the average price level over the fluid milk category but also helped raise the absolute and relative share of retailers' margin (Agridea, 2012; Réviron et al., 2017).

Although it reveals some of the challenges facing the fluid milk market, this overview of the literature does not provide a comprehensive picture of the priorities and needs of today's consumers with respect to purchasing decisions. By analyzing the importance assigned to a large spectrum of purchasing attributes, a recent study done by Harwood and Drake (2018) de- 
livered valuable insights into US fluid milk consumers and allow them to be clustered into 4 different segments. However, the choice of attributes tested in that study and the summary of purchasing motives (see the first section of the introduction) suggested that US and European consumers do not face the same offer and do not allocate the same importance to various product attributes. Thus, the objective of this study was to expand our understanding of fluid milk consumers' choices by analyzing the influence of a broad spectrum of intrinsic and extrinsic attributes on Swiss consumers' choice of cow fluid milk and by clustering consumers into various segments sharing common purchasing motives. The current market offer was analyzed in a store check before being compared with the results of the clustering procedure. The aim of this procedure was to identify underexploited market niches and offer possible explanations for past successes and failures. We conclude with suggestions for targeted product concepts and category adaptations.

\section{MATERIALS AND METHODS}

\section{Data Collection and Sample}

A paper and pencil survey was sent out to a random sample of citizens living in 4 cantons of Switzerland (Bern, Argovia, Solothurn, and Lucerne) whose addresses were retrieved from the telephone directory. The mailing included a cover letter introducing the study, the questionnaire itself, and a postage-paid preaddressed return envelope. The person responsible for the household's milk supply was asked to complete the questionnaire.

One reminder was sent after $1 \mathrm{wk}$; this procedure resulted in 886 returned questionnaires (39\% response rate). After excluding questionnaires with more than $25 \%$ missing answers $(\mathrm{n}=167)$ and those failing a simple consistency check of 2 similar questions $(\mathrm{n}=7)$, 712 questionnaires remained for data analysis. In 645 of those, all questions related to buying motives were answered and the questionnaires could be included in the clustering procedure. The recruitment method, based on telephone directory entries and requiring participants to be responsible for the milk supply, led to the underrepresentation of the youngest age groups, many of whom still live with their parents and are not responsible for the food supply, and to the overrepresentation of women, who still perform most of the household chores in Swiss households. The data were collected between April and May 2015 as part of a larger project and were subject to a confidentiality clause for $3 \mathrm{yr}$.

\section{Questionnaire}

The questionnaire was 15 pages, in 4 sections, and took participants approximately 25 min to complete. Participants were first questioned about their fluid milk consumption habits in term of frequency, quantity, and preferred variant(s) regarding fat content and heat treatment, as well as about their supply source(s) and the way(s) they consume milk (e.g., pure, flavored, with coffee, with cereals, as an ingredient in recipes, or processed in homemade dairy products). In section 2 , respondents were asked to indicate, on a 6-point Likert scale $(1=$ do not agree at all, $6=$ agree completely $)$, what importance they attach to 3 intrinsic (taste, fat content, and shelf life) and 8 extrinsic (packaging size, packaging design, consumer price, fair farmer price, species-appropriate feeding, animal-friendly husbandry, sustainability, and local production) product attributes when buying fluid milk. These 11 attributes were used in the cluster analysis to segment the consumers. The third section was dedicated to questions related to motives underlying food and fluid milk choice. Respondents had to indicate their degree of agreement to 19 randomly listed statements on the same 6-point Likert scale from before. These 19 items corresponded to 6 constructs, whose internal consistency was checked and means computed before being used in the description of the different consumer segments that emerged from the cluster analysis. A summary of these 6 scales and items including reliability statistics (Cronbach's $\alpha$ ) and sources is provided in Table 1 . The questionnaire ends up with a series of socio-demographic questions related to sex, age, living area, education level, nationality, and income level.

\section{Store Check}

The Swiss food and near-food retail market is dominated by 2 large supermarket chains, which together generate $58 \%$ of the market sales revenues. For the store check, we analyzed the range of products offered by the 7 largest players (a total market share of $78 \%$ ), and therefore assumed to be representative of the choice available to Swiss consumers. We conducted a complete review of the refrigerated and ambient fluid milk assortment offered by each of the 7 distributors, visiting 2 or 3 of their largest stores in both the German- and French-speaking country regions during spring 2019.

\section{Statistical Analysis}

All statistical analyses were conducted using IBM SPSS Statistics 25 (IBM Corp., Armonk, NY). After 
eliminating 1 of the 11 attributes (species-appropriate feeding) due to a multicollinearity problem indicated by the collinearity diagnostic in SPSS (Field, 2018), the 10 remaining attributes were subjected to hierarchical cluster analysis using Ward's method and the squared Euclidean distance. Solutions between 2 and 8 clusters were generated and evaluated. The agglomeration schedule was examined and the percentage change in the clustering coefficient was computed for 2 through 8 clusters. Ignoring the 2 -cluster solution according to Backhaus et al. (2016), the most prominent step occurred when 3 clusters combined into 2, highlighting the 3 -cluster solution as the best one. The 3 clusters were then subjected to statistical analysis using general linear models. Unequal cluster sizes and heteroscedasticity led to the use of Welch and Brown-Forsythe robust tests and Games-Howell post hoc test. The general linear models were then used to test whether significant differences existed between the 3 clusters regarding food and fluid milk choice motives, fluid milk consumption habits, supply sources, and socio-demographic variables.

\section{RESULTS AND DISCUSSION}

\section{Cluster Analysis}

Three consumer segments with distinct buying patterns were identified in the sample population: the un- compromising consumers (24\%), the locavores (56\%), and the indifferent consumers $(20 \%)$. The mean scores for the 3 clusters obtained on the variables used for segmentation as well as the post hoc analysis results are presented in Table 2 and detailed in the following sections.

The description of each segment is complemented with information related to their respective food and milk choice motives (Table 3), socio-demographic profile (Table 4), fluid milk consumption habits (Table 5), and supply source preferences (Table 6).

The Uncompromising Consumers (24\%). The uncompromising consumers stand out because of their high and numerous expectations of the milk they intend to buy. They attach great importance to taste, reduced fat content, long shelf life, and packaging size while seeking the lowest prices. Interestingly, the same consumers acknowledge that they are somewhat overwhelmed by the many options available to them. This consumer segment pays attention to health and diet, is women-dominated, and includes a higher proportion of older consumers. Uncompromising consumers shop mainly in large supermarkets, sometimes in countryside small supermarkets, but rarely visit artisans' shops.

The Locavores (56\%). As their name suggests, the locavores, which make up more than half of the sample, ensure that they primarily consume milk of local origin. Locavores seek products from controlled supply chains, are not interested in fat-reduced milk, and are less

Table 1. Items on food and milk choice motives per construct used to describe the segments, including the scale's Cronbach's $\alpha$ and source

\begin{tabular}{ll}
\hline Scale and item & Source \\
\hline 1. Nutrition and health consciousness (Cronbach's $\alpha=0.89)$ & \\
I am very interested in nutrition-related topics & Dittus et al. $(1995)^{1}$ \\
Decisions regarding my diet are very important to me & Nittus al. $(1995)^{1}$ \\
I am very concerned about my health & New \\
I am attentive to the evolution of my state of health & Dittus et al. $(1995)^{2}$ \\
Keeping a healthy diet is very important to me & Dittus et al. $(1995)^{2}$ \\
I take care to eat healthy & New \\
2. Need for supply chain control (Cronbach's $\alpha=0.70)$ & \\
I want to know where my product comes from and who made it & \\
It is important to me that food is well controlled & New \\
I only buy food that I know is well controlled & \\
3. Keen interest in milk (Cronbach's $\alpha=0.84)$ & Grunert et al. $(1993)^{1}$ \\
I would be interested in information about milk & \\
I would like to intensively deal with the subject of milk & \\
4. Preference for organic food (Cronbach's $\alpha=0.88)$ & New \\
Whenever possible, I buy organic food & \\
Organic production is very important to me & Brunner et al. $(2010)$ \\
5. Escaping the overwhelming offer (Cronbach's $\alpha=0.83)$ & \\
There are too many different milk brands & \\
There are too many different (milk) marks/schemes & \\
6. Food waste avoidance (Cronbach's $\alpha=0.70)$ & \\
I try to shop in a way that I don't have leftovers to throw away & \\
I regret it a lot if I have to throw food away & \\
\hline &
\end{tabular}


Table 2. Mean scores ${ }^{1}$ of the clustering variables and post hoc test results by clusters

\begin{tabular}{|c|c|c|c|}
\hline Clustering variable & $\begin{array}{c}\text { Uncompromising } \\
\text { consumers } \\
(24 \% ; \mathrm{n}=154)\end{array}$ & $\begin{array}{c}\text { Locavores } \\
(56 \% ; \mathrm{n}=361)\end{array}$ & $\begin{array}{c}\text { Indifferent } \\
\text { consumers } \\
(20 \% ; \mathrm{n}=130)\end{array}$ \\
\hline Packaging size*** & $5.34^{\mathrm{a}}$ & $3.76^{\mathrm{b}}$ & $3.88^{\mathrm{b}}$ \\
\hline Packaging design $* * *$ & $2.51^{\mathrm{a}}$ & $1.80^{\mathrm{b}}$ & $1.88^{\mathrm{b}}$ \\
\hline Taste*** & $5.64^{\mathrm{a}}$ & $5.10^{\mathrm{b}}$ & $4.62^{\mathrm{c}}$ \\
\hline Consumer price*** & $4.84^{\mathrm{a}}$ & $3.16^{\mathrm{b}}$ & $4.02^{\mathrm{c}}$ \\
\hline Reduced fat content $* * *$ & $4.81^{\mathrm{a}}$ & $2.44^{\mathrm{b}}$ & $3.22^{\mathrm{c}}$ \\
\hline Fair farmer price ${ }^{* * *}$ & $5.35^{\mathrm{a}}$ & $5.15^{\mathrm{a}}$ & $2.84^{\mathrm{b}}$ \\
\hline Shelf life ${ }^{* * *}$ & $5.62^{\mathrm{a}}$ & $4.45^{\mathrm{b}}$ & $4.57^{\mathrm{b}}$ \\
\hline Animal-friendly husbandry*** & $5.60^{\mathrm{a}}$ & $5.44^{\mathrm{a}}$ & $3.21^{\mathrm{b}}$ \\
\hline Sustainability*** & $5.26^{\mathrm{a}}$ & $5.19^{\mathrm{a}}$ & $2.85^{\mathrm{b}}$ \\
\hline Local production*** & $4.99^{\mathrm{a}}$ & $5.24^{\mathrm{b}}$ & $2.99^{\mathrm{c}}$ \\
\hline
\end{tabular}

sensitive to prices. They favor fresh milk (pasteurized) over long-life milk (UHT) and show interest in organic foods. Locavores buy part of their food directly from artisans or producers and purchase occasionally at farmers' markets and exotic or organic grocery stores. Compared with other segments, locavores make few of their purchases at discounters.

The Indifferent Consumers (20\%). Indifferent consumers are set apart for their modest expectations for the taste, origin, and production conditions under which the milk they buy was produced. Similarly, indifferent consumers' behavior is marked by the absence of leading buying motives; they show very little interest in organic food production and do not seek to be better informed about the dairy sector. Compared with other segments, indifferent consumers make a larger proportion of their purchases at discounters and ignore alternative supply channels, such as specialty stores or farmers' markets. This segment encompasses more men and younger people.

The result of the segmentation highlighted that fluid milk consumers are far away from a homogeneous group. In contrast, each of the 3 disclosed segments showed distinct interests and needs, which should be addressed separately within a dedicated marketing mix. Furthermore, the modest number of segments and their respectable size support this approach.

The "pay less, get more" marketing strategy, which has been adopted by most retailers since hard discounters entered the Swiss market (Grass et al., 2017; Jucker et al., 2019), has had a lasting impact on consumer behavior and more specifically on uncompromising consumers. This segment, which makes most of their purchases in large supermarkets, has been consistently trained to seek best-value offers and applies only this strategy when buying fluid milk. Accustomed to modern and sophisticated product concepts, uncompromising consumers are looking for the ultimate offer at the lowest price. The attention they devote to maintaining a healthy diet may explain their preference for semiskimmed or part-skimmed over whole milk. Reducing fat content, however, has a major effect on milk taste and texture (O'Sullivan, 2017, p. 186). Because taste has been rated as the most important buying motive by these consumers, a new product concept combining health and taste arguments would be expected to fit this segment (see also McCarthy et al., 2017). In practice, the development of a milk in which part of the fat is

Table 3. Assessment of food and milk choice motives by clusters ${ }^{1}$

\begin{tabular}{lcccc}
\hline Food and milk choice motive & $\begin{array}{c}\text { Uncompromising } \\
\text { consumers }\end{array}$ & Locavores & $\begin{array}{c}\text { Indifferent } \\
\text { consumers }\end{array}$ & Overall \\
\hline Nutrition and health consciousness*** & $4.84^{\mathrm{a}}$ & $4.69^{\mathrm{a}}$ & $4.25^{\mathrm{b}}$ & 4.63 \\
Need for supply chain control & $4.92^{\mathrm{a}}$ & $4.98^{\mathrm{a}}$ & $4.01^{\mathrm{b}}$ & 4.77 \\
Keen interest in milk*** & $3.11^{\mathrm{a}}$ & $3.23^{\mathrm{a}}$ & $2.39^{\mathrm{b}}$ & 3.03 \\
Preference for organic food $* * *^{\mathrm{a}}$ & $3.34^{\mathrm{a}}$ & $3.93^{\mathrm{b}}$ & $2.50^{\mathrm{c}}$ & 3.50 \\
Escaping the overwhelming offer* & $4.49^{\mathrm{a}}$ & $4.22^{\mathrm{ab}}$ & $4.03^{\mathrm{b}}$ & 4.25 \\
Food waste avoidance*** & $5.48^{\mathrm{a}}$ & $5.47^{\mathrm{a}}$ & $5.01^{\mathrm{b}}$ & 5.38 \\
\hline
\end{tabular}

${ }^{\mathrm{a}-\mathrm{c}}$ Means within a row with different superscripts differ $(P<0.05)$.

${ }^{1}$ Mean scores on a 6 -point Likert scale; $1=$ "do not agree at all" to $6=$ "agree completely."

${ }^{*} P<0.05,{ }^{* * *} P<0.001$. 
Table 4. Demographic features by clusters

\begin{tabular}{|c|c|c|c|c|}
\hline Feature & $\begin{array}{l}\text { Uncompromising } \\
\text { consumers }\end{array}$ & Locavores & $\begin{array}{l}\text { Indifferent } \\
\text { consumers }\end{array}$ & $\begin{array}{l}\text { Overall } \\
\text { sample }\end{array}$ \\
\hline$\overline{\text { Average age }(\mathrm{yr})^{*}}$ & $55.1^{\mathrm{a}}$ & $53.2^{\mathrm{ab}}$ & $49.8^{\mathrm{b}}$ & 53.0 \\
\hline \multicolumn{5}{|l|}{ Education level (\%) } \\
\hline None & 1 & 2 & 2 & 2 \\
\hline Primary & 7 & 3 & 6 & 4 \\
\hline Apprenticeship & 46 & 42 & 41 & 43 \\
\hline Secondary & 5 & 7 & 5 & 6 \\
\hline Professional school & 24 & 24 & 20 & 23 \\
\hline Technical college & 9 & 13 & 12 & 12 \\
\hline University & 8 & 10 & 15 & 11 \\
\hline Household net income* $\left(\mathrm{CHF}^{1}\right)$ & 6,333 & 6,902 & 7,062 & 6,801 \\
\hline$<3,000 \mathrm{CHF}(\%)$ & 10 & 8 & 5 & 8 \\
\hline $3,000-4,500 \mathrm{CHF}(\%)$ & 17 & 14 & 14 & 15 \\
\hline $4,501-6,000 \mathrm{CHF}(\%)$ & 21 & 19 & 18 & 19 \\
\hline $6,001-7,500 \mathrm{CHF}(\%)$ & 23 & 20 & 23 & 21 \\
\hline 7,501-9,000 CHF $(\%)$ & 13 & 14 & 14 & 14 \\
\hline $9,001-10,500 \mathrm{CHF}(\%)$ & 8 & 10 & 10 & 10 \\
\hline$>10,500 \mathrm{CHF}(\%)$ & 9 & 16 & 15 & 14 \\
\hline \multicolumn{5}{|l|}{$\operatorname{Sex} * *(\%)$} \\
\hline Female & 72 & 64 & 53 & 64 \\
\hline Male & 28 & 36 & 47 & 36 \\
\hline \multicolumn{5}{|l|}{ Residential area (\%) } \\
\hline City & 12 & 16 & 20 & 16 \\
\hline Agglomeration & 33 & 34 & 29 & 33 \\
\hline Countryside & 55 & 50 & 50 & 51 \\
\hline \multicolumn{5}{|l|}{ Nationality (\%) } \\
\hline Swiss & 96 & 97 & 96 & 96 \\
\hline Other & 4 & 3 & 4 & 4 \\
\hline
\end{tabular}

$\overline{\mathrm{a}, \mathrm{b}}$ Means within a row with different superscripts differ $(P<0.05)$.

${ }^{1}$ Where 1 CHF $=$ US $\$ 1.01$ in July 2019 (X-Rates, 2019).

${ }^{*} P<0.05,{ }^{* *} P<0.01$.

replaced by milk protein is an approach that minimizes the body loss that results from skimming (Phillips et al., 1995; Quiñones et al., 1997, 1998; Akoh, 1998; Misawa et al., 2016) while simultaneously following the trend of low-fat, high-protein foods (Barbano, 2017). To meet uncompromising consumers' high expectations for convenience, inferred by the importance they give to packaging size and shelf life, products intended for

Table 5. Fluid milk consumption and preferences by clusters (mean values or scores)

\begin{tabular}{|c|c|c|c|c|}
\hline Item & $\begin{array}{l}\text { Uncompromising } \\
\text { consumers }\end{array}$ & Locavores & $\begin{array}{l}\text { Indifferent } \\
\text { consumers }\end{array}$ & Overall \\
\hline \multirow{2}{*}{\multicolumn{5}{|c|}{ Fluid milk consumption form ${ }^{1}$}} \\
\hline & & & & \\
\hline As a drink with addition of flavoring component(s) & 1.77 & 1.79 & 1.59 & 1.74 \\
\hline With coffee & 2.87 & 2.76 & 2.66 & 2.76 \\
\hline With cereals & 2.24 & 2.21 & 2.03 & 2.18 \\
\hline Skim milk** $(0.1 \%)$ & $0.55^{\mathrm{a}}$ & $0.17^{\mathrm{b}}$ & $0.45^{\mathrm{a}}$ & 0.32 \\
\hline Semi skim milk*** $(1.5 \%)$ & $1.51^{\mathrm{a}}$ & $0.74^{\mathrm{b}}$ & $1.06^{\mathrm{ab}}$ & 0.99 \\
\hline Part-skim milk** $(2.5-2.7 \%)$ & $2.57^{\mathrm{a}}$ & $2.03^{\mathrm{b}}$ & $2.09^{\mathrm{b}}$ & 2.18 \\
\hline Whole milk*** $(\geq 3.5 \%)$ & $1.18^{\mathrm{a}}$ & $2.50^{\mathrm{b}}$ & $1.98^{\mathrm{c}}$ & 2.10 \\
\hline $\mathrm{UHT}^{* * *}$ (long-life milk) & $2.55^{\mathrm{a}}$ & $1.58^{\mathrm{b}}$ & $2.62^{\mathrm{a}}$ & 2.03 \\
\hline Pasteurized $^{2 * * *}$ (fresh milk) & $2.22^{\mathrm{a}}$ & $2.89^{\mathrm{b}}$ & $2.17^{\mathrm{a}}$ & 2.59 \\
\hline
\end{tabular}

${ }^{\mathrm{a}-\mathrm{c}}$ Means within a row with different superscripts differ $(P<0.05)$.

${ }^{1}$ Measured on a 5 -point Likert scale: $0=$ never, $1=$ rarely, $2=$ sometimes, $3=$ often, $4=$ (almost) always.

${ }^{2}$ Mechanical treatments intended to extend the shelf life of pasteurized milk (e.g., microfiltration or bactofugation) do not need to be labeled in Switzerland; Swiss consumers cannot differentiate between pasteurized milk produced with or without one of these treatments.

** $P<0.01,{ }^{* * *} P<0.001$. 
Table 6 . Food supply sources by clusters ${ }^{1}$

\begin{tabular}{|c|c|c|c|c|}
\hline Supply source & $\begin{array}{l}\text { Uncompromising } \\
\text { consumers }\end{array}$ & Locavores & $\begin{array}{l}\text { Indifferent } \\
\text { consumers }\end{array}$ & Overall \\
\hline Large supermarkets** & $2.67^{\mathrm{a}}$ & $2.41^{\mathrm{b}}$ & $2.42^{\mathrm{b}}$ & 2.47 \\
\hline Discounters** & $0.66^{\mathrm{a}}$ & $0.45^{\mathrm{b}}$ & $0.69^{\mathrm{a}}$ & 0.55 \\
\hline Countryside small supermarkets & 0.78 & 0.84 & 0.73 & 0.80 \\
\hline Artisans' shops (e.g., bakeries, dairies)* & $0.41^{\mathrm{a}}$ & $0.66^{\mathrm{b}}$ & $0.54^{\mathrm{ab}}$ & 0.58 \\
\hline Exotic and organic grocery stores** & $0.09^{\mathrm{ab}}$ & $0.17^{\mathrm{a}}$ & $0.05^{\mathrm{b}}$ & 0.13 \\
\hline Farmers' markets* & $0.11^{\mathrm{ab}}$ & $0.17^{\mathrm{a}}$ & $0.05^{\mathrm{b}}$ & 0.13 \\
\hline Direct from producer*** & $0.23^{\mathrm{a}}$ & $0.53^{\mathrm{b}}$ & $0.16^{\mathrm{a}}$ & 0.39 \\
\hline
\end{tabular}

this segment should be packaged in containers of different sizes, including small ones (e.g., 0.5 and $1 \mathrm{~L}$ ), and undergo a heat treatment that allows them to be stored for several weeks without having to handle them with excessive care. Thus, UHT and extended shelf life (ESL) milk are 2 potential options - the latter preserving slightly better the taste of raw milk. The high sensitivity of uncompromising consumers to animal-friendly husbandry and fair producer prices outlines a potential avenue for a new premium-priced product concept. The communication around this concept should build on a few easy-to-understand messages, including the price premium, which goes directly to the farmer, and one emblematic measure in favor of animal-friendly husbandry that is not yet implemented in the conventional Swiss cattle farming system (e.g., full grazing). Finally, the feeling expressed by consumers of being somewhat overwhelmed by the offer could be seized by large supermarkets and translated into a noticeable reduction of their fluid milk assortment or it will translate in an opportunity for discounters to capture a larger share of this segment, provided that they develop and include one or both of the above-suggested product concepts in their straightforward offer.

Although Swiss uncompromising consumers seem to have a unique profile, the locavores share most of their priorities and preferences with the US premium consumers outlined by Harwood and Drake (2018). Locavores seem to attach equal importance to all 3 sustainability dimensions. Thus, a marketing concept emphasizing a holistic approach from farm to shelf might be a sound approach to fit several of their needs. Not only milk production but also processing and, if possible, distribution should occur locally. The milk collection area, the name of the dairy (manufacturer), and portraits of the farmers and milkmen should feature prominently on the packaging and form the central pillar of the communication concept. These efforts should illustrate the local and sustainable nature of the product and build up consumer trust. Our analysis of locavores' prefer- ences highlights that this milk should be a pasteurized, full-fat product, possibly complemented with a partskimmed variant. Voluntarily renouncing technologies that extend the shelf life of pasteurized milk (e.g., high pasteurization, membrane filtration, or bactofugation) as well as any fat standardization would reinforce the "natural" and "authentic" character of the product and, if adopted, be used to address locavores' values. Moreover, locavores showed a significant but not absolute preference for organic food; thus, to optimally meet the needs of this large segment, the local milk should ideally be available in both organic and conventional forms.

In strong contrast to the locavores, indifferent consumers are not concerned by sustainability or fairness issues related to fluid milk production, nor are they interested in learning more about this subject. Their basic expectations - a milk that tastes good and has a sufficient shelf life - can be fulfilled with any regular long-life milk apart from skim milk. Indifferent consumers are not particularly price sensitive but will not pay for any "added value" concept; they can be compared, to some extent, with the opportunistic consumers described by Harwood and Drake (2018). Thus, it is perhaps the convenient, straightforward offer more than price that leads them to make part of their purchases from discounters. A summary of suggested product concepts is presented in Table 7 .

\section{Store Check}

The store check, also called the assortment review, was conducted in spring 2019 at the 7 largest Swiss retailers (see Table 8). It revealed that basic and budget milks represent a large proportion of the assortment and are available in almost any combination of heat treatment (UHT or ESL), fat content (low fat, semiskimmed, part-skimmed, or standardized whole milk), packaging size $(0.25,0.5,1,1.5,1.75$, or $2 \mathrm{~L})$, and packaging type (carton or bottle). Organic milks appeared 
to be the second most common type of milk found on retailers' shelves; they are also available in most of the attributes' combinations listed above. Pasture-raised or hay milk, local milk, and mountain milk are 3 other milk types present on the refrigerated shelves of at least 2 of the 7 retailers considered in this study. Lactose-free milk is also found at most retailers. The store check also confirmed that the entire fluid milk offer was of Swiss origin and that the name of the dairy (manufacturer) was rarely mentioned on the packaging. Brands were also absent from most milk packaging and seem to be of very little importance for this product category. For completeness, it should be notified that goat, sheep, and plant-based milk substitutes were all well represented on the shelves. However, these products were outside the scope of this study.

The store check revealed that all but one of the product concepts developed from the cluster analysis can be found on the shelves of at least one of the largest retailers. None of them, however, offer more than 2 correctly designed product concepts at the national level. The protein-enhanced, semi-skim milk-the first of the 2 product concepts targeting uncompromising consumers - is not yet available on the market. Two retailers offer protein-enhanced, low-fat milk in 1-L containers. However, these products mismatch the high expectations of uncompromising consumers, either in terms of taste or convenient, small packaging. The second product concept targeting this segment, fair milk, is available at one discounter. Both the premium for the farmer and the frequent access to the outdoors and pasture for the cows are addressed on the packaging. This milk is only available in part-skimmed, pasteurized, and microfiltered 1-L packages, a choice that fits well the preferences of uncompromising consumers, other than the limited choice in terms of packaging size. A local fair milk concept has been developed in the region of Geneva. This milk, which guarantees farmers a substantial premium but does not offer any added value in terms of animal welfare, is sold in all supermar- ket chains in the canton of Geneva. In contrast, 2 large supermarket chains launched their own sustainability program with the aim of improving animal welfare and promoting animal-friendly husbandry and species-appropriate feeding on the farm producing the milk used for their basic and budget products. However, without any mention on the packaging or at the point of sale, these initiatives remain unknown to most consumers. Considering the dominant weight of locavores in our sample population, product concepts addressing their wants are not sufficiently present on store shelves. Indeed, none of the retailers managed to offer locavores a choice between a conventional local milk and an organic local milk in all country regions. Conversely, a large proportion of the available milk references are likely to fulfil the needs of the smallest and least-demanding segment disclosed in this study: the indifferent consumers. This is due both to the very basic, and therefore easily met, expectations of this segment and to the oversized assortment of very similar products.

\section{Suggestions for Category Adaptation}

Because consumers in all 3 segments reported making most of their purchases in supermarkets, category managers would be advised to work on the development and inclusion of all suggested product concepts in their assortment (see Table 7). The introduction of a protein-enhanced, semi-skim milk, in 2 different container sizes $(0.5$ and $1 \mathrm{~L})$, is probably the easiest way to attract demanding consumers to the stores. Indeed, the development of this product is based on available raw material, relies on known technologies, and can be marketed within a simple communication strategy.

Conversely, fair milk, 100\% local milk, and 100\% local organic milk all require fundamental adaptations in the purchasing strategy and potentially modifications in the supply chain. The development of a fair milk requires retailers to work closely with their milk producers or, alternatively, to consider sourcing part of

Table 7. Summary of the suggested product concepts

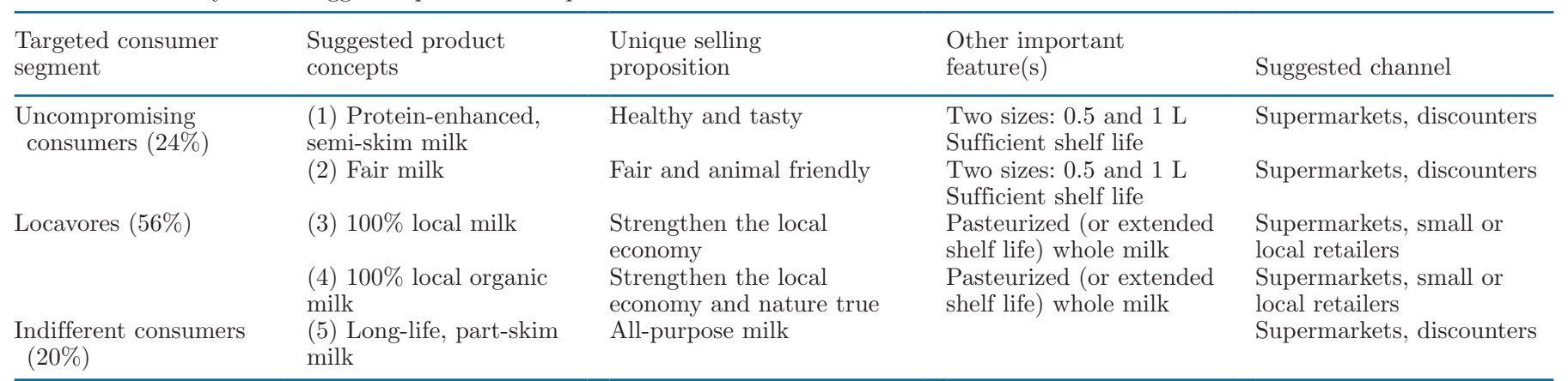


their milk from new producers or a farmers' organization. Offering both 100\% local milk and 100\% local organic milk at the national level is a challenging task, especially for strong centralized organizations. This is probably one of the reasons for their disparate presence on supermarket shelves and their total absence at discounters. The difficulties begin with the interpreta- tion of the term "local," the definition of production regions, and the search for processors in each region. Despite these pitfalls, the importance of the locavores and their moderate price sensitivity alone justify the need for supermarkets to engage in the development and listing of both variants of $100 \%$ local milk. This measure would allow them to offer a targeted and

Table 8. Overview of the Swiss fluid milk supply ${ }^{1}$

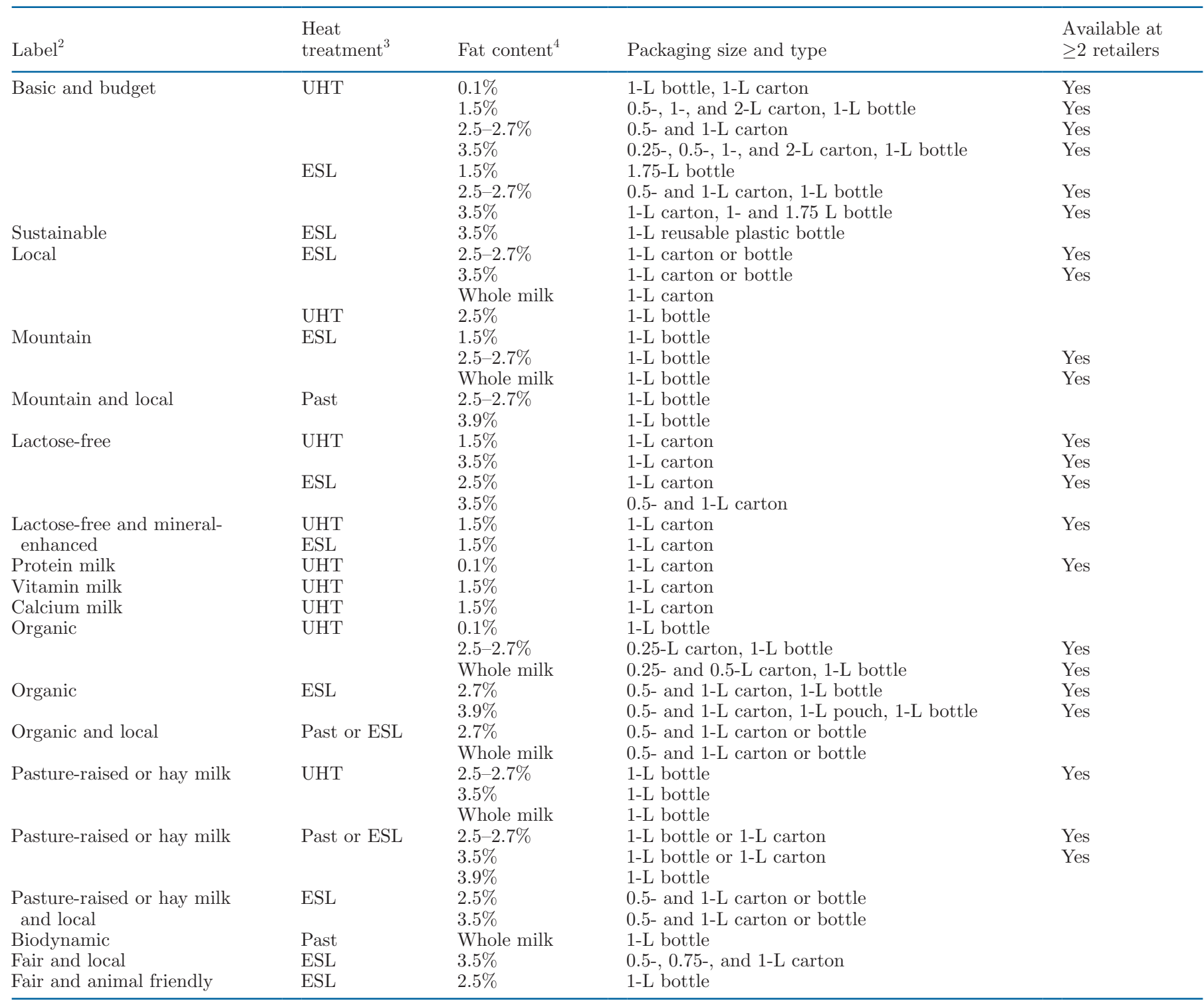

${ }^{1}$ The overview was based on a store check conducted in spring 2019 in the 7 largest retailers of Switzerland; only cow milk products were considered.

${ }^{2}$ Enriched $=$ enriched with one or more mineral salts; Biodynamic $=$ special type of organic farming that includes various esoteric concepts. Soil fertility, plant growth, and livestock care are considered as ecologically interrelated tasks. Biodynamic milk cannot be homogenized.

${ }^{3} \mathrm{ESL}=$ extended shelf life; heat treatment or a combination of heat and mechanical treatment allowing the shelf life of pasteurized milk to be extended (e.g., high pasteurization, pasteurization and microfiltration, or pasteurization and bactofugation). In Switzerland the 2 latter treatments (microfiltration and bactofugation) do not need to be labeled; thus, ESL milks are labeled as high-pasteurized or pasteurized milk. Past $=$ pasteurized $\left(\sim 72^{\circ} \mathrm{C}, 15 \mathrm{~s}\right)$.

${ }^{4}$ Whole milk $=$ unstandardized full-fat milk with a minimum of $3.9 \%$ fat. 
comprehensive choice, thereby preventing their migration toward smaller and more reactive local suppliers. Discounters are not locavores' preferred channel; thus, overall costs and gains, including strategic and corporate image issues, must be assessed before making any decision regarding a local milk project. Unlike at discounters, large supermarkets' shelves are filled with a vast assortment of conventional milks, which differ slightly from each other in size, type of container, fat content, and heat treatment. However, it is not clear which segment this wide range of products with little differentiation is aimed at. Indifferent consumers buy these milks but this segment has very few requirements in term of convenience; therefore, the assortment could easily be reduced to 2 to 4 references of long-life milk varying in fat content (e.g., standardized whole milk and semi- or part-skimmed) and perhaps in size (e.g., 0.5 and $1 \mathrm{~L}$ ), as discounters do already. Two further recurring product concepts appeared when examining the offer on the Swiss market (see Table 1): pastureraised or hay milk and mountain milk. Pasture-raised milk was first launched in the Swiss market in 2011. The concept is based on a catalog of measures favoring biodiversity and animal-friendly husbandry; each farmer chooses which measures they want to apply on their farm. This milk represents a sort of middle ground between conventional and organic milk, both in term of promises and consumer price. The numerous measures and the farmers' freedom in their application have made it very difficult to develop a simple communication concept that underscores the added value of the product without compromising the image of conventional milk (which still represents the largest share of the retail offer and should not be devalued). This weakness was certainly at the root of the difficult product launch. A recent report on food and sustainability (Kamm et al., 2015) supported this hypothesis, demonstrating that Swiss consumers do not understand the differences between the various sustainability labels with which they are faced. Unlike pasture-raised milk, mountain milk is primarily a marketing concept that capitalizes on the affection Swiss consumers have for mountain lifestyle and imagery and, by extension, for mountain products. In the variant proposed by one retailer, the product can also be seen as a sort of fair milk, because a small price premium is paid to mountain farmers. Based on the segmentation results, the necessity of both pastureraised (or hay milk) and mountain milk on the shelves is questionable. The persistence of these milks on the shelves does not necessarily signify their pertinence; the results of the present study suggest rather that it is not the pasture-raised or mountain arguments but potentially other product attributes that lead consumers to buy these milks.

\section{Limitations and Further Studies}

In Switzerland, the term "sustainability" is mostly, if not uniquely, associated with the environmental aspect of the concept and used in everyday language as a synonym for environmental friendliness. This explains why respondents were asked to indicate the importance they attach to, among other attributes, fair farmer price and local production - 2 aspects related to the economic and social dimensions of sustainable milk productionas well as to sustainability, rather than as an indicator of ecological production. This choice is, however, disputable and it potentially impaired the measurement of the importance of each sustainability dimension in milk choice. More generally, carrying out a focus group discussion on attributes considered by Swiss consumers when buying fluid milk would have complemented the literature review and allowed us to validate the choice of the variables and adapt the wording before questionnaire development.

The pertinence of certain concepts, such as pastureraised milk and mountain milk, could be tested via a follow-up study using choice analysis. Testing consumers' interest for combinations of several attributes, including options with and without the concepts in question, would allow us to determine which product attributes really matter and the premium the consumer is willing to pay for each of them. The same method could be used as part of an assortment-reduction process to determine key references to keep on the shelves. Along the same lines, using the Q-methodology to study consumers' conceptual representations of the fluid milk category could help to even more precisely describe the identified profiles (Brard and Lê, 2018; Vidal et al., 2020).

\section{CONCLUSIONS}

Despite their sometimes very large shelves and numerous references, Swiss suppliers have not yet succeeded in fully understanding the needs of their consumers and developing corresponding products. Although a large share of the minimally differentiated offer could probably be eliminated without affecting the sales, the added-value concepts should be redesigned to better match the expectations of the uncompromising consumers and locavores. These 2 segments, which represent $80 \%$ of the sampled population and are those ready to pay a premium for a product matching their needs, should be addressed with a small number of targeted product concepts that combine the right characteristics and are, if necessary, customized in a few variations. If the products are developed and marketed according to our recommendations, 5 product concepts broken 
down to a maximum of 4 variants could be sufficient to address the needs of the 3 consumer segments. Depending on their strategic positioning, retailers as well as other milk supply chain actors are urged to focus on 1 , a subset, or all 5 concepts. Redefining the retailer's fluid milk assortment according to consumer needs and desires will likely not be sufficient to bring consumption back to the level of the last century; this effort could nevertheless boost sales while reducing assortment depth and thus generate higher sales per square foot.

\section{ACKNOWLEDGMENTS}

The authors thank Mirjam Gfeller (former student at HAFL, Zollikofen, Switzerland) for her help in developing the questionnaire and collecting the data. The authors have not stated any conflicts of interest.

\section{REFERENCES}

Agridea. 2012. Formation des prix dans les filières agricoles de l'arc lémanique. Accessed Jan. 31, 2020. https://agridea.abacuscity .ch/abauserimage/Agridea_2_Free/2345_1_F.pdf?xet= 1579237762581.

Akoh, C. C. 1998. Fat replacers. Food Technol. 52:47-53.

Backhaus, K., B. Erichson, W. Plinke, and R. Weiber. 2016. Multivariate Analysemethoden: eine anwendungsorientierte Einführung. 14., überarbeitete und aktualisierte Auflage. Lehrbuch. Springer Gabler, Berlin, Germany.

Barbano, D. M. 2017. A 100-Year Review: The production of fluid (market) milk. J. Dairy Sci. 100:9894-9902. https://doi.org/10 .3168/jds.2017-13561.

Bosanac, S., B. Guyonnet, C. Karsenti, V. Pilet, and Mi. Poulet. 2017. L'économie laitière en chiffres - édition 2017. CNIEL (Centre national interprofessionnel de l'économie laitière), Paris, France.

Brard, M., and S. Lê. 2018. Adaptation of the Q-methodology for the characterization of a complex concept through a set of products: From the collection of the data to their analysis. Food Qual. Prefer. 67:77-86. https://doi.org/10.1016/j.foodqual.2017.06.010.

Brunner, T. A., K. van der Horst, and M. Siegrist. 2010. Convenience food products. Drivers for consumption. Appetite 55:498-506. https://doi.org/10.1016/j.appet.2010.08.017.

Cessna, J., and J. Law. 2017. Fluid beverage milk sales quantities by product (million pounds). Accessed Jan. 31, 2020. https://www .ers.usda.gov/webdocs/DataFiles/48685/fluidmilk.xlsx?v=474.5.

Charrondiere, U. R., D. Haytowitz, and B. Stadlmayr. 2012. FAO/ INFOODS Databases, Density Database Version 2.0. FAO, Rome, Italy.

Conseil Fédéral. 2017. Marché laitier. Perspectives. Accessed Jan. 31, 2020. https://www.blw.admin.ch/dam/blw/fr/ dokumente/Services/Publikationen/Berichte/Perspektiven\%20 im\%20Milchmarkt.pdf.download.pdf/Bericht_Postulat_15.3380 _Perspektiven_im_Milchmarkt_FINAL_30.03.2017_FF.pdf.

Davis, C. G., D. Dong, D. Blayney, S. T. Yen, and R. Stillman. 2012. U.S. fluid milk demand: A disaggregated approach. Int. Food Agribus. Manag. Rev. 15:25-50.

de Graaf, S., E. J. Van Loo, J. Bijttebier, F. Vanhonacker, L. Lauwers, F. A. M. Tuyttens, and W. Verbeke. 2016. Determinants of consumer intention to purchase animal-friendly milk. J. Dairy Sci. 99:8304-8313. https://doi.org/10.3168/jds.2016-10886.

Delley, M., and T. A. Brunner. 2018. Household food waste quantification: Comparison of two methods. Br. Food J. 120:1504-1515. https://doi.org/10.1108/BFJ-09-2017-0486.

Dittus, K. L., V. N. Hillers, and K. A. Beerman. 1995. Benefits and barriers to fruit and vegetable intake: Relationship between at- titudes and consumption. J. Nutr. Educ. 27:120-126. https://doi .org/10.1016/S0022-3182(12)80802-8.

Emberger-Klein, A., K. Menrad, and D. Heider. 2016. Determinants of consumers' willingness-to-pay for fairly-produced, locally grown dairy products. Germ. J. Agric. Econ. 65:94-111.

Esmerino, E. A., J. Ferraz, E. Tavares Filho, L. Pinto, M. Freitas, A. Cruz, and H. Bolini. 2017. Consumers' perceptions toward 3 different fermented dairy products: Insights from focus groups, word association, and projective mapping. J. Dairy Sci. 100:8849-8860. https://doi.org/10.3168/jds.2016-12533.

Eurostat. 2018. Milk and Milk Product Statistics-Statistics Explained. Accessed April 15, 2019. https://ec.europa.eu/eurostat/statistics -explained/index.php?title=Milk_and_milk_product_statistics.

Field, A. 2018. Discovering Statistics using IBM SPSS Statistics. Sage, London, UK.

FranceAgriMer. 2017. La filière lait de vache Bilan 2016. Données et Bilans Lait. FranceAgriMer, Montreuil, France.

Grass, M., T. Scheffczyk, V. Schubert, and J. Stoll. 2017. Die Kosten des Schweizer Detailhandels im internationalen Vergleich. BAK Basel Economics AG, Basel, Switzerland.

Grunert, K. G., K. Bruns $\varnothing$, and S. Bisp. 1993. Food-related life style: Development of a cross-culturally valid instrument for market surveillance. MAPP Working paper no. 12.

Gulseven, O., and M. Wohlgenant. 2017. What are the factors affecting the consumers' milk choices? Agric. Econ.-. Zemed. Ekon. 63:271-282. https://doi.org/10.17221/335/2015-AGRICECON.

Harwood, W. S., and M. A. Drake. 2018. Identification and characterization of fluid milk consumer groups. J. Dairy Sci. 101:8860-8874. https://doi.org/10.3168/jds.2018-14855.

INLAC. 2016. El Sector Lácteo en España Datos de producción, industria y consumo (2008-2015). INLAC, Madrid, Spain. IPLC. La consommation. Accessed March 8, 2018. http://iplc.fr/Le-lait-au -quotidien/La-consommation.

Jucker, S., A. Christen, M. Fuhrer, and M. Hotz. 2019. Schweizer Detailhandel im internationalen Wettbewerb. Swiss Economics Retail Outlook. Credit Suisse, Zurich. Switzerland.

Kamm, A., G. Hildesheimer, E. Bernold, and D. Eichhorn. 2015. Ernährung und Nachhaltigkeit in der Schweiz: Eine verhaltensökonomische Studie. FehrAdvice \& Partners AG, Zürich, Switzerland.

Lanfranchi, M., A. Zirilli, A. Passantino, A. Alibrandi, and C. Giannetto. 2017. Assessment of milk consumer preferences: Identifying the choice factors through the use of a discrete logistic model Br. Food J. 119:2753-2764. https://doi.org/10.1108/BFJ-04-2017 $-0210$.

Lehnert, S. 2010. Faire Milch: Geschäfte in der Nische. Top Agrar Online. Accessed Jan. 31, 2020. https://www.topagrar.com/rind/aus -dem-heft/faire-milch-geschaefte-in-der-nische-9695246.html.

Leuenberger, H. U. 2017. Rapport agricole 2017-Lait et produits laitiers. Accessed March 5, 2018. https://agrarbericht.ch/fr/ marche/produits-animaux/lait-et-produits-laitiers.

Lopez, E., and R. A. Lopez. 2009. Demand for differentiated milk products: Implications for price competition. Agribusiness 25:453465. https://doi.org/10.1002/agr.20219.

Maehle, N., N. Iversen, L. Hem, and C. Otnes. 2015. Exploring consumer preferences for hedonic and utilitarian food attributes. Br. Food J. 117:3039-3063. https://doi.org/10.1108/BFJ-04-2015 -0148 .

McCarthy, K. S., M. Parker, A. Ameerally, S. L. Drake, and M. A. Drake. 2017. Drivers of choice for fluid milk versus plant-based alternatives: What are consumer perceptions of fluid milk? J. Dairy Sci. 100:6125-6138. https://doi.org/10.3168/jds.2016-12519.

Misawa, N., D. M. Barbano, and M. Drake. 2016. Influence of casein as a percentage of true protein and protein level on color and texture of milks containing 1 and 2\% fat1. J. Dairy Sci. 99:5284-5304. https://doi.org/10.3168/jds.2016-10846.

MIV. 2017. Milch und mehr - die deutsche Milchwirtschaft auf einen Blick. Milchindustrie-Verband e.V., Berlin, Germany.

Newton, J. 2017. Trends in beverage milk consumption. Farm Bureau Market Intelligence. Accessed Jan. 31, 2020. https://www.fb.org/ market-intel/trends-in-beverage-milk-consumption. 
O'Sullivan, M. G. 2017. A Handbook for Sensory and Consumer-Driven New Product Development: Innovative Technologies for the Food and Beverage Industry. Woodhead Publishing, Duxford, UK.

Obrist, L., and D. Erdin. 2014. Nahrungsmittelbilanz (NMB08), Methode. Union Suisse des paysans, Brugg, Switzerland.

OMSCO. 2017. Organic Milk Market Report 2017. Organic Milk Suppliers Cooperative Ltd. (OMSCo). Accessed Jan. 31, 2020. https:/ /organic-market.info/print.pdf.

OSAV (Office fédéral de la sécurité alimentaire et des affaires vétérinaires). 2017. Consommation de lait et de produits laitiers, Etude 2014/15. Accessed Jan. 31, 2020. https://www.blv.admin.ch/dam/ $\mathrm{blv} / \mathrm{fr} /$ dokumente/lebensmittel-und-ernaehrung/ernaehrung/fi -menuch-milch.pdf.download.pdf/fi-menuch-milch.pdf.

Paus, M., E. Hidber, S. Réviron, and M. Pidoux. 2016. Valorisation des produits de l'agriculture fribourgeoise. Agridea, Lausanne, Switzerland. https://www.fr.ch/sites/default/files/contens/sagri/ _www/files/pdf88/filagro-fribourg_-rapport-final.pdf.

Phillips, L. G., M. L. Mcgiff, D. M. Barbano, and H. T. Lawless. 1995. The influence of nonfat dry milk on the sensory properties, viscosity, and color of lowfat milks. J. Dairy Sci. 78:2113-2118. https:// doi.org/10.3168/jds.S0022-0302(95)76838-2.

Pinto, L., H. Silva, S. Kuriya, P. Maçaira, F. Oliveira, A. Cruz, E. Esmerino, and M. Freitas. 2018. Understanding perceptions and beliefs about different types of fermented milks through the application of projective techniques: A case study using Haire's shopping list and free word association. J. Sens. Stud. 33:e12326. https: //doi.org/10.1111/joss.12326.

Quiñones, H. J., D. M. Barbano, and L. G. Phillips. 1997. Influence of protein standardization by ultrafiltration on the viscosity, color, and sensory properties of skim and 1\% milk. J. Dairy Sci. 80:31423151. https://doi.org/10.3168/jds.S0022-0302(97)76285-4.

Quiñones, H. J., D. M. Barbano, and L. G. Phillips. 1998. Influence of protein standardization by ultrafiltration on the viscosity, color, and sensory properties of 2 and 3.3\% milks. J. Dairy Sci. 81:884894. https://doi.org/10.3168/jds.S0022-0302(98)75647-4.

Réviron, S., P. Python, F. Gresset, and M. Estève. 2017. Distribution de valeur en filière. Agridea, Lausanne, Switzerland.

Schröck, R. 2012. The organic milk market in Germany is maturing: A demand system analysis of organic and conventional fresh milk segmented by consumer groups. Agribusiness 28:274-292. https:// doi.org/10.1002/agr.21298.
Speight, K. C., A. Schiano, W. Harwood, and M. Drake. 2019. Consumer insights on prepackaged Cheddar cheese shreds using focus groups, conjoint analysis, and qualitative multivariate analysis. J. Dairy Sci. 102:6971-6986. https://doi.org/10.3168/jds.2018-16209.

SSB. 1986. Statistique laitière de la Suisse 1985. Schweizerisches Bauernsekretariat, Brugg, Switzerland.

Tempesta, T., and D. Vecchiato. 2013. An analysis of the territorial factors affecting milk purchase in Italy. Food Qual. Prefer. 27:3543. https://doi.org/10.1016/j.foodqual.2012.06.005.

USP. 2001. Statistique laitière de la Suisse 2000. USP (Union suisse des paysans), TSM (Treuhandstelle Milch GmbH), SMP (SchweizerMilchproduzenten), SSB (SekretariatdesSchweizerischen Bauernverbandes). Accessed Jan. 31, 2020. https://www.sbv-usp .ch/fileadmin/sbvuspch/04_Medien/Publikationen/MiSta/Mista _2000_f.pdf

USP. 2017. Statistique laitière de la Suisse 2016. USP (Union suisse des paysans), TSM (Treuhandstelle Milch GmbH), SMP (SchweizerMilchproduzenten), SSB (SekretariatdesSchweizerischen Bauernverbandes). Accessed Jan. 31, 2020. https://www.sbv -usp.ch/fileadmin/sbvuspch/04_Medien/Publikationen/MiSta/ MISTA_2016.pdf.

Vidal, V. A., C. Paglarini, M. Freitas, L. Coimbra, E. Esmerino, M. Pollonio, and A. Cruz. 2020. Q Methodology: An interesting strategy for concept profile and sensory description of low sodium salted meat. Meat Sci. 161:108000. https://doi.org/10.1016/j.meatsci .2019.108000.

Wolf, C. A., G. T. Tonsor, and N. J. Olynk. 2011. Understanding U.S. consumer demand for milk production attributes. J. Agric. Resour. Econ. 36:326-342.

X-Rates. 2019. Exchange Rate Average (Swiss Franc, US Dollar)-XRates, Monthly Average. Accessed July 8, 2019. https://www.x -rates.com/calculator $/$ from $=$ CHF \& to $=U S D \& a m o u n t=1$.

Zarrouki, K. 2015. Dairy Products-Western Europe. Agriculture and Agri-Food Canada, Global Analysis, Ottawa, ON, Canada.

\section{ORCIDS}

Mathilde Delley ํㅏㄴ https://orcid.org/0000-0003-3701-1881 Thomas A. Brunner ๑ https://orcid.org/0000-0002-6770-6548 